\title{
OSMOTIC DEHYDRATION OF FIG AND PLUM
}

\author{
MOUSTAFA, SOHAIR E.; H. I. ABED EL-HAKIM and HEMET I. MAATOUK
}

\author{
Horticultural Crops Tech. Res. Dept., Food Tech. Res. Inst., ARC, Giza, Egypt.
}

(Manuscript received 11 October 2016)

\begin{abstract}
$\mathrm{T}$ he present study was carried out to investigate the effect of osmotic partially dehydration and edible coating using of carboxy methyl cellulose (CMC) on physical, chemical and organoleptic characteristics on Fig and Plum. Chemical, physical properties and sensory evaluation were carried out for fresh and osmotic dehydrated Fig and Plum. The obtained results reveal that fresh Fig had a high content of total soluble solids (T.S.S) \%, crude protein, total ash and total acidity compared to those reported by fresh Plum. Meanwhile, fresh Plum moisture content was higher than that of fresh Fig the same results for crude fiber, ether extract, total sugars, both reducing, non-reducing sugars, $\mathrm{pH}$ value and L-Ascorbic acid were observed. It was noticed that there were significant differences in total sugars between treatments No.T3, T6 (Air dried Fig and Plum immerged in (CMC) solution + calcium chloride solution + sucrose solution) and treatments No. T2, T5 (Air dried Fig and Plum immerged in sucrose solution) compared to control T1, T4 (Air dried Fig and Plum without any treatments). It was observed that there were significant differences between all treatments in total sugars and reducing sugars contents compared to control samples. The obtained results also, recorded that the phytochemical content for all treatments was lower than that observed for fresh samples, meanwhile, treatments No. $(T 3, T 6)$ had the highest content of phytochemical component compared to other treatments. Using of edible coating protects phytochemical component for dried Fig and Plum. Sensory quality parameters of the coating and osmotic dehydrated Fig and Plum (T3 and T6) showed an excellent organoleptic characteristics of color, taste, odor, texture, and overall palatability as compared to other once. On The other hand, it was noticed that edible coating causes the increasing of shear strength due to decrease of solute up take to texture of samples. Meanwhile, the rate of weight loss, water loss and solid gain was higher in air dried samples immerged in osmotic agent compared to these values which reported by air dried samples immerged in edible coating and osmotic agent in both dehydrated Plum and Fig. It could be concluded that the dehydrated Fig and Plum prepared by using an edible coating agent (CMC) and sucrose syrup at T.S.S. (50\%) shows good organoleptic properties and overall acceptability. The chemical and nutritional quality are also not affected due to use edible coating and osmotic drying treatment, and it was best for preparation of dehydrated Fig and Plums with good quality.
\end{abstract}

Key Words: Fig, Plum, edible coating, osmotic dehydration, chemical, physical properties and sensory evaluation. 


\section{INTRODUCTION}

Fig (Ficus carica) a deciduous tree belonging to the Moraceae family, is one of the earliest cultivated fruit trees. Fig is a delicious, nutritive fruit and has medicinal properties that may reduce the risk of cancer and heart disease. On the other hand (Oliveira, et al., 2010b) stated that Fig fruit is consumed fresh, dried, preserved, canned, and candied forms. In the Mediterranean region, it is used for alcohol and wine production and in Europe for a Fig-coffee preparation. Fresh and dried Fig are especially rich in fiber, trace minerals, antioxidant, polyphenols, proteins, sugars, organic acids, and volatile compounds that provide a pleasant characteristic aroma. Plums are a significant source of nutrients, dietary fiber and antioxidants, such as phenolic compounds (Milala, et al., 2013).

In spite of the fact that there is a variety of Plum, Fig processed products, such as, marmalades, jellies, juices, and soft drinks, these fruits are commonly consumed in the fresh stage. Because, shelf life of fruits and vegetables, as well as seasonal products, is relatively short and taking into account that they are valuable raw materials for food industry, so, it is very important to increase their sustainability. Conventional preservation methods (convective drying, candying, freezing, etc.), commonly employed to preserve food materials, often cause decreases in nutritional and sensory properties of treated fruits and vegetables (loss of vitamins, changes in color, altered taste and texture, bad dehydration). The main disadvantages of the convective drying are high energy consumption and loss of the thermo labile components of food. On the other hand, among different food preservation techniques, osmotic dehydration (OD is a simple immersion of food (fruit, vegetable, meat and fish) in concentrated solutions, where the osmotic pressure difference between the product and hypertonic solution, is the driving force of the dehydration process.). It was proved to be one of the most useful, primarily due to the low temperature and energy requirements, low waste material and good quality of final product it was observed by (Panagiotou, et al., 1999).

El-Aouar, et al., (2006) revealed that the type of osmotic agent is a very important factor that determines the rate of diffusion. The common solute types used as an osmotic agent are sucrose, glucose, sorbitol, glycerol, glucose syrup, corn syrup and fructo-oligosaccharide. Generally, low molecular weight osmotic agent easier penetrates into the cell of fruit compared to high molecular weight osmotic agent.

Edible coatings are fine layers of digestible material added to a food product. There is some indication that, during the drying process, the application of these coatings may reduce the loss of aroma, color and nutrients by reducing oxygen 
diffusion into the food, minimizing solute incorporation and maintaining the product's physical integrity. The barrier properties of coatings mostly depend on their composition and the method used for their fabrication Zhao and Chang, 1995).

For the purposes of the osmotic membrane process, edible coatings should have the following properties: good mechanical strength (gel strength), satisfactory sensory properties, easy and rapid film formation with simple techniques, high water diffusivity and maintenance (of the coating) in an intact state without dissolving into the osmotic solution (Camirand, et al., 1992) and he noticed that the advantages of the process may include the following:

- It may allow for greater rates of osmotic dehydration compared to those obtained without coating.

- It may also minimize microbial contamination and oxidation activity.

- Coating may provide greater product integrity and physical strength to food pieces, which can withstand mixing (throughout processing) and physical impact (during handling, storage and transportation).

- It may allow the use of lower molecular weight osmotic agents with higher osmotic pressures (e.g., $\mathrm{NaCl}$ ) and reduced solute penetration.

- It may reduce losses of desired constituents, e.g., colorants, flavor compounds and nutrients.

- Finally, it may give greater esthetic appeal, especially for products with clear polysaccharide coatings.

Khin, et al., (2007) reported that aqueous solutions of potato starch, corn starch, sodium alginate, low methoxylpectinate, high methoxylpectinate, chitosan, ethyl cellulose, carboxyl methyl cellulose and maltodextrin were applied to coat fruits and vegetables to control solute uptake. As the coating serves as an extra barrier to the mass transfers during osmotic dehydration, it is well anticipated that both solute uptake and water loss will be reduced in coated food materials. It was found that most coatings could prevent the large solute uptake well without affecting too much of water loss. However,

Thus, the objectives of this study were to study the effect of edible coatings and osmotic agents on moisture loss and solid gain during osmotic dehydration of Fig and Plum.

\section{MATERIALS AND METHODS}

\section{Materials}

Fig (Ficus carica) was purchased from farm near Giza governorate and Plum (Prunus domestics) was purchased from the local market and washed with tap water 
and dried, blanched in $\mathrm{NaOH}$ solution $(0.5 \%)$ at $100^{\circ} \mathrm{C}$ for 30 seconds and following the removal of the fruits quickly and washed with running water to remove traces of alkaline. Fruits were divided into equal sex treatments as follows:-

T1: - Air dried (using a hot air-circulated oven at $60 \mathrm{C}^{\circ}$ for $24 \mathrm{hr}$.) Fig without any treatments (control).

T2: - Air dried (using a hot air-circulated oven at $60 \mathrm{C}^{\circ}$ for $24 \mathrm{hr}$.) Fig immerged in osmotic agent (sucrose solution only 50\%) for 3 hours.

T3: - Air dried (using a hot air-circulated oven at $60 \mathrm{C}^{\circ}$ for $24 \mathrm{hr}$.) Fig immerged in edible coating carboxy methyl cellulose $(0.5)$ for 30 seconds, then, the calcium chloride solution (2\%) for $2 \mathrm{~min}$. and osmotic agent sucrose solution (50\%) for 3 hours.

T4: - Air dried (using a hot air-circulated oven at $60 \mathrm{C}^{\circ}$ for $26 \mathrm{hr}$.) Plum without any treatment (control).

T5: -Air dried (using a hot air-circulated oven at $60 \mathrm{C}^{\circ}$ for $26 \mathrm{hr}$.) Plum immerged in osmotic agent sucrose solution only (50\%) for 3 hours.

T6: - Air dried (using a hot air-circulated oven at $60 \mathrm{C}^{\circ}$ for $26 \mathrm{hr}$.) Plum immerged in edible coating carboxy methyl cellulose $(0.5)$ for 30 seconds, then, the calcium chloride solution (2\%) for $2 \mathrm{~min}$. and osmotic agent sucrose solution (50\%) for 3 hours.

\section{Coating treatment:-}

Fig and Plum immersed in a carboxy methyl cellulose (CMC) solution (0.5\%) for 30 second and then put in calcium chloride solution (2\%) for 2 minutes. Then they dried at $55-60^{\circ} \mathrm{C}$ for $5-10$ minutes to fix the coating layer on the samples, according to (Farzanch, et al., 2011).

\section{Osmotic treatment:-}

According to (Farzanch, et al., 2011) osmotic dehydration was carried out at $40^{\circ} \mathrm{C}$ under atmospheric pressure. The coated and uncoated samples were placed in $2000 \mathrm{ml}$ beakers and kept submerged in sucrose hypertonic solution (50\%) about 180 minutes. The material to solution ratio was $1: 4(w / w)$. The beakers were kept in a thermostat at $40^{\circ} \mathrm{C}$ for 180 minutes. Samples were taken every 20 minutes and measured TSS for 3 hours, as well as the solution. Finally, the material was removed from osmotic solutions, washed with water and gently blotted to remove the excessive water. All treatments were weighed and dried by using a hot air ventilation oven at $60^{\circ} \mathrm{C}$ for about 24 hours (for Fig) but, for 26 hours for (Plum). Samples were packed in polyethylene until analysis. 


\section{Analytical Methods}

\section{Chemical analysis:-}

All Samples were determined as follows: Moisture, total soluble solids (TSS), $\mathrm{pH}$ value, total titratable acidity, crude fiber, ether extract, total ash, L- Ascorbic acid, crude protein, reducing, non-reducing and total sugar were determined according to the method of AOAC (2012).

\section{Determination of total phenolic compounds (TPC):-}

Total phenolic compounds (TPC) were determined by the Folin- Cicalteau method as described by (Singleton, et al., 1999), with minor modifications, based on colorimetric oxidation/reduction reaction of phenols. Gallic acid was used for calibration curve. Results were expressed as mg Gallic acid (GAE).

\section{Determination of total flavonoids:-}

Total flavonoids content was measured by using aluminum chloride calorimetric method, as described by (Chang, et al., 2002). The results were expressed as catechin equivalents (CE) in $\mathrm{mg} / 100 \mathrm{~g}$ of dried extract.

\section{Determination of antioxidant activity:-}

The antioxidant activity of free and bound phenolic extracts was measured by using 1, 1-diphenyl-2-picrylhydrazyl (DPPH) scavenging as previously described by (Hung and Morita, 2009).

\section{Determination of total anthocyanins:-}

Total monomeric anthocyanin pigment was extracted and determined according to the method described by (Lee, et al., 2005).

\section{Calculation of osmotic parameters:-}

The osmotic process is adequately represented by the following parameters: weight loss (WL), solid gain (SG) and water loss (WR) of the material immersed in the osmotic solution. There are different ways to define these quantities, but the most widely used definitions are: the water loss as net water lost from a fresh sample calculated on initial sample mass, the solid gain as the net increase in solids calculated on initial sample mass. Weight loss (WL), water loss (WLs) and solid gain (SG) were calculated for the osmosed Fig and Plum fruit resulted from each treatment according to (Correa et al., 2010) as follows:-

$$
\begin{array}{ll}
\text { WL (\%) }=X_{o}^{w} M_{0}^{\circ}-X_{f}^{w} M_{f}^{\circ} / M_{0}^{\circ} & \mathrm{x} 100 \\
\text { SG (\%) }=X_{f}^{s t} M_{f}^{\circ}-X_{0}^{s t} M_{0}^{\circ} / M_{0}^{\circ} & \mathrm{x} 100 \\
\text { WLs (\%) }=M_{0}^{\circ}-M_{f}^{\infty} / M_{0}^{\circ} & \mathrm{x} 100
\end{array}
$$

Where $M_{0}^{=}=$initial sample weight $(\mathrm{kg}), M_{f=}^{\circ}$ final sample weight $(\mathrm{kg}), X_{0}^{w}=$ Initial moisture content (\%), $X_{f}^{w}=$ Final moisture content (\%), $X_{0}^{s t}=$ Initial solids content (\%) ,$X_{f}^{s t}=$ Final solids content $(\%)$. 


\section{Texture profile analysis:-}

Osmotic dehydration sample texture was determined by a universal testing machine (Cometech, B type, Taiwan). Flat head stainless cylindrical probe of $2 \mathrm{~mm}$ diameter was used for penetration test. The start of penetration test was the contact of the probe and sample surface, finish - when the probe penetrated the tissues to $50 \%$ of sample height. The probe speed was $1 \mathrm{~mm} \mathrm{~s}-1$. (Bourne, 2002).

\section{Sensory evaluation:-}

Sensory evaluation of osmotic dehydration samples was conducted by more than ten panelists (chosen by random) in the Food Technology Research Institute, according to the method of (Lindley, et al., 1993). Sensory attributes (color, taste, odor, texture and overall palatability) for osmotic dehydration samples, the sensory attributes (color, taste, odor, texture and overall palatability) were evaluated directly after osmotic dehydration.

\section{Statistical Analysis:-}

The results were statistically analyzed by analysis of variance (ANOVA) using the procedure by statistical analysis system (SAS) program. Significant differences were determined at the level $P \geq 0.05$.

\section{RESULTS AND DISCUSSION}

\section{Chemical composition of Fig and Plum.}

The Chemical composition of Fig and Plum fruit has determined (on dry weight basis) and shown its potential health benefits (Table 1). It has revealed that Fig has moderate amount of protein (3.31\%). While, crude fiber content $(1.78 \%)$ was good. It has a very low amount of ether extract $(0.61 \%)$ so it can be helpful for weight loss. Fig were found to contain moisture (82.93\%) and high ash content $(4.10 \%)$. Moisture content effects on the texture, taste, appearance and stability of foods so it is related to storage attributes of the dried fruit. L-Ascorbic acid content was $(18.10 \mathrm{mg} / 100 \mathrm{~g})$.

Table 1. Chemical composition of Fig and Plum (on dry weight basis).

\begin{tabular}{|c|c|c|c|l|c|}
\hline \multirow{2}{*}{ Constituents } & \multicolumn{2}{|c|}{ Value } & \multirow{2}{*}{ Constituents } & \multicolumn{2}{c|}{ Value } \\
\cline { 2 - 5 } \cline { 5 - 6 } Moisture (\%) & Fig & Plum & Fig & Plum \\
\hline Total soluble solids (\%) & $14.25 \pm 0.25$ & $11.12 \pm 0.33$ & pH value & $4.23 \pm 0.43$ & $5.21 \pm 0.35$ \\
\hline Crude protein (\%) & $3.31 \pm 0.11$ & $1.20 \pm 0.23$ & $\begin{array}{c}\text { Total titratable acidity } \\
\text { (As citric acid) (\%) }\end{array}$ & $5.31 \pm 0.25$ & $0.71 \pm 0.08$ \\
\hline Crude fiber (\%) & $1.78 \pm 0.32$ & $2.5 \pm 0.41$ & Total sugars (\%) & $13.15 \pm 1.48$ & $10.26 \pm 1.23$ \\
\hline Total ash (\%) & $4.10 \pm 0.51$ & $2.89 \pm 0.32$ & sugars (\%) & $7.32 \pm 1.22$ & $6.65 \pm 0.89$ \\
\hline Ether extract (\%) & $0.61 \pm 0.09$ & $1.10 \pm 0.15$ & Non-reducing sugars (\%) & $5.83 \pm 1.05$ & $3.61 \pm 1.52$ \\
\hline
\end{tabular}




\section{Mean values \pm standard deviation}

On the other hand, total soluble solids T.S.S (\%), pH value and total titratable acidity (As citric acid) (\%) were found to be $14.25 \%, 4.23$ and $5.31 \%$, respectively. Meanwhile, Table (1) shows that the edible portion of Plum fruit contained $2.89 \%$ total ash. However, the moisture content (86.01\%). While, the ether extract content $(1.1 \%)$, the crude protein content (1.2\%). However, the content of crude fiber $(2.5 \%)$ which is the indigestible carbohydrate and needed for digestion in man. Vitamin (C) content of the edible portion (170.14 mg/100g). While, T.S.S. (\%), pH value and total titratable acidity (as citric acid) (\%) found to be $11.12 \%, 5.21$ and $0.71 \%$ respectively. These results in good agreement with those reported by (Farid and Neda, 2014) except in the case of vitamin (C) which it's value was lower than that reported by (Delia -Gabriela, et al., 2012). On the other hand, it was observed that fresh Plum had the highest content of total sugars, reducing and non-reducing sugars and the lowest contents were recorded by fresh Fig.

\section{Sugar contents.}

Sugar contents were determined for dehydrated Plum and Fig fruit. From the obtained data which are presented in Table (2) it was observed that there were significant differences between all treatments. The content of total sugars and reducing sugars were lower for $(\mathrm{T} 1, \mathrm{~T} 4)$ than which recorded by $(\mathrm{T} 3, \mathrm{~T} 6)$ and $(\mathrm{T} 2$, T5).

Table 2. Sugar content of fresh, osmotic dehydrated Fig and Plum.

\begin{tabular}{|c|c|c|c|}
\hline Treatments Sugars & Non- reducing sugars (\%) & $\begin{array}{c}\text { Reducing sugars } \\
(\%)\end{array}$ & Total sugars (\%) \\
\hline \multicolumn{4}{|c|}{ Fig } \\
\hline T1 & $35.87^{\mathrm{c}} \pm 1.11$ & $29.65^{\mathrm{c}} \pm 1.26$ & $6.21^{\mathrm{b}} \pm 1.14$ \\
\hline T2 & $77.48^{\mathrm{a}} \pm 0.98$ & $57.98^{\mathrm{a}} \pm 0.88$ & $19.5^{\mathrm{a}} \pm 1.42$ \\
\hline T3 & $69.61^{\mathrm{b}} \pm 0.85$ & $50.41^{\mathrm{b}} \pm 0.67$ & $19.20^{\mathrm{a}} \pm 0.99$ \\
\hline \multicolumn{3}{|c|}{ Plum } \\
\hline T4 & $37.29^{\mathrm{c}} \pm 1.05$ & $31.53^{\mathrm{c}} \pm 0.97$ & $5.75^{\mathrm{b}} \pm 1.10$ \\
\hline T5 & $78.64^{\mathrm{a}} \pm 0.68$ & $57.80^{\mathrm{a}} \pm 1.32$ & $20.84^{\mathrm{a}} \pm 0.78$ \\
\hline T6 & $71.06^{\mathrm{b}} \pm 0.75$ & $50.75^{\mathrm{b}} \pm 1.27$ & $20.31^{\mathrm{a}} \pm 0.86$ \\
\hline
\end{tabular}

Mean values \pm standard deviation, Mean values followed by the same letter vertically do not differ at $p=$ 0.05 of significance

T1: - Air dried Fig without any treatments (control).

T2: - Air dried Fig immerged in sucrose solution only

T3: - Air dried Fig immerged in (CMC) solution + calcium chloride solution + sucrose solution.

T4: - Air dried Plum without any treatment (control).

T5: -Air dried Plum immerged in sucrose solution only.

T6: - Air dried Plum immerged in (CMC) solution + calcium chloride solution + sucrose solution.

Meanwhile, the results revealed that non-reducing sugars content was low for $(T 1, T 4)$ compared to those reported by other treatments. These could be due to 
coating treatments. These results were in agreement with those recorded by (Mišljenović, et al., 2009), who observed that penetration of the solute, primarily sucrose molecules, from the osmotic solution into the sample can be limited by applying edible coating.

\section{Phytochemical Analysis}

Phytochemical analysis of fresh and dehydrated Plum and Fig included a screening of total phenolic compounds, total flavonoids and total anthocyanins contents. Values of total phenolic, flavonoids and total anthocyanins were calculated Table (3). Total phenolic compounds tabulated in Table (3). They were 20.27, 21.07 and 43.61 $\mathrm{mg} / 100$ (on dry weight basis) for T1, T2 and T3, respectively for Fig samples.

Meanwhile, total phenolic compounds in Plum samples, were higher than those recorded by Fig samples, and they were 135.10, 139.12 and 145.35 mg/100 for T4, T5 and T6, respectively. It was noticed that all previous values in both Fig and Plum treatments were less than those recorded by fresh samples, which were 61.95 and $198.53 \mathrm{mg} / 100$ for Fig and Plum samples, respectively. That was maybe due to dry at low temperature and for a long period, these results in harmony with which recorded by (Gupta, et al., 2011) whom are noticing that Drying at low temperature resulted, reduction in the phenol content and long drying time might have destroyed some phenolic compounds.

Table 3. Effect of some treatments on the phytochemical content of Fig and Plum (on dry weight basis).

\begin{tabular}{|c|c|c|c|c|}
\hline Treatments & $\begin{array}{l}\text { Total phenolic } \\
\text { compounds } \\
(\mathrm{mg} / 100 \mathrm{~g})\end{array}$ & $\begin{array}{l}\text { Total flavonoids } \\
\text { (mg/100g) }\end{array}$ & $\begin{array}{l}\text { Antioxidant } \\
\text { activity (\%) }\end{array}$ & $\begin{array}{c}\text { Total } \\
\text { anthocyanin } \\
(\mathrm{mg} / 100 \mathrm{~g})\end{array}$ \\
\hline \multicolumn{5}{|c|}{ Fig } \\
\hline Fresh Fig & $61.95^{\mathrm{a}} \pm 1.90$ & $4.54^{\mathrm{a}} \pm 0.01$ & $40.75^{a} \pm 2.05$ & $12.5^{\mathrm{a}} \pm 1.20$ \\
\hline $\mathrm{T} 1$ & $20.27^{c} \pm 1.02$ & $2.25^{\mathrm{b}} \pm 0.15$ & $30.81^{b} \pm 2.01$ & $4.95^{c} \pm 0.20$ \\
\hline $\mathrm{T} 2$ & $21.07^{c} \pm 1.20$ & $2.25^{b} \pm 0.01$ & $22.41^{\mathrm{c}} \pm 1.02$ & $6.01^{\mathrm{c}} \pm 1.90$ \\
\hline T3 & $43.61^{b} \pm 1.01$ & $2.28^{b} \pm 0.05$ & $31.15^{b} \pm 2.07$ & $8.75^{b} \pm 2.20$ \\
\hline \multicolumn{5}{|c|}{ Plum } \\
\hline Fresh Plum & $198.53^{a} \pm 2.03$ & $7.16^{a} \pm 0.15$ & $47.20^{\mathrm{a}} \pm 2.03$ & $29.73^{a} \pm 0.98$ \\
\hline $\mathrm{T} 4$ & $135.10^{c} \pm 0.60$ & $4.28^{b} \pm 0.01$ & $30.69^{c} \pm 2.05$ & $18.48^{\mathrm{c}} \pm 0.10$ \\
\hline $\mathrm{T} 5$ & $139.12^{\mathrm{b}} \pm 1.00$ & $4.55^{b} \pm 0.05$ & $32.34^{b} \pm 2.17$ & $19.06^{\mathrm{C}} \pm 0.10$ \\
\hline T6 & $145.35^{\mathrm{b}} \pm 1.30$ & $4.61^{b} \pm 0.03$ & $37.40^{\mathrm{bc}} \pm 1.3$ & $22.98^{\mathrm{b}} \pm 1.60$ \\
\hline
\end{tabular}

Mean values \pm standard deviation, Mean values followed by the same letter vertically do not differ at $p=$ 0.05 of significance

T1: - Air dried Fig without any treatments (control).

T2: - Air dried Fig immerged in sucrose solution only

T3: - Air dried Fig immerged in (CMC) solution + calcium chloride solution + sucrose solution.

T4: - Air dried Plum without any treatment (control).

T5: -Air dried Plum immerged in sucrose solution only.

T6: - Air dried Plum immerged in (CMC) solution + calcium chloride solution + sucrose solution. 
On the other hand, the results in Table (3) concerning total flavonoids for fresh and treatments under investigation revealed was a significant difference $(p<$ 0.05 ) between fresh samples and all treatments for both Fig and Plum samples, but, there was non-significant differences between treatments, it was clear that flavonoid content decreased on all treatments compared to fresh samples because of thermal degradation of flavonoids during processing. These results were in good agreement with which recorded by (Ioannou, et al., 2012). Whom mentioned similar findings, and revealed that heating breakdown some phytochemicals, which affected cell wall integrity and caused a migration of some flavonoid component, and thermal degradation occurred during processing in the presence of oxygen by direct oxidation mechanism or through the action of oxidizing enzymes i.e. polyphenol oxidase (PPO), in addition of degradation of flavonoid is occurring not only due to temperature and heating, it may also depend on other parameters such as $\mathrm{pH}$, the presence of oxygen, and the presence of other phytochemicals in the medium.

On the contrary, the results of the same table show that anthocyanin content of fresh samples Fig and Plum found to be 12.5 and $29.73 \mathrm{mg} / 100$. Meanwhile, it was clear that T6, had the highest values of anthothyanin followed by T3 and the lowest was T4, T1 when compared to other once, it could be due to the high content of anthocyanin in Plum fruit. Data in Table (3) recorded that fresh and process sample which had a high content of phytochemical contained higher antioxidant activity due to the release of a free phenolic fraction. In the same trend (Emine and Hisil, 2013) reported similar results. Finally, from previous results it was noticed that samples which treated with carboxy methyl cellulose as coating agent protected phytochemical compared to samples which drying with or without immerged in osmotic solution.

\section{Sensory evaluation}

The results of the sensory profile analyses are shown in Table (4). Sensory quality parameters of the coating and osmotic dehydrated Fig and Plum (T3 and T6) showed excellent organoleptic characteristics of color, taste, odor, texture, and overall palatability as compared to other treatments ( $\mathrm{T} 2$ and $\mathrm{T} 5$ ) as well as to control samples (T1 and T4). 
Table 4. organoleptic characteristics of osmotic dehydration Fig and Plum.

\begin{tabular}{|c|c|c|c|c|c|}
\hline \multirow{2}{*}{\begin{tabular}{c}
\multirow{2}{*}{ Parameters } \\
\cline { 2 - 6 }
\end{tabular}} & Color & Taste & Odor & Texture & $\begin{array}{c}\text { Overall } \\
\text { palatability }\end{array}$ \\
\cline { 2 - 6 } & $5.8^{\mathrm{c}} \pm 1.82$ & $6.1^{\mathrm{c}} \pm 1.54$ & $6.3^{\mathrm{c}} \pm 1.59$ & $6.25^{\mathrm{c}} \pm 1.59$ & $6.15^{\mathrm{c}} \pm 1.67$ \\
\hline $\mathrm{T} 1$ & $7.5^{\mathrm{b}} \pm 1.82$ & $7.7^{\mathrm{b}} \pm 1.54$ & $7.75^{\mathrm{b}} \pm 1.59$ & $7.9^{\mathrm{b}} \pm 1.59$ & $8.1^{\mathrm{b}} \pm 1.67$ \\
\hline $\mathrm{T} 2$ & $9.5^{\mathrm{a}} \pm 1.82$ & $9.1^{\mathrm{a}} \pm 1.54$ & $8.9^{\mathrm{a}} \pm 1.59$ & $9.1^{\mathrm{a}} \pm 1.59$ & $9.6^{\mathrm{a}} \pm 1.67$ \\
\hline T3 & \multicolumn{7}{|c|}{ Plum } \\
\hline T4 & $5.9^{\mathrm{c}} \pm 1.79$ & $6.3^{\mathrm{c}} \pm 1.68$ & $6.8^{\mathrm{b}} \pm 1.44$ & $6.3^{\mathrm{b}} \pm 1.68$ & $5.8^{\mathrm{c}} \pm 1.67$ \\
\hline T5 & $8.4^{\mathrm{b}} \pm 1.79$ & $7.75^{\mathrm{b}} \pm 1.68$ & $8.7^{\mathrm{a}} \pm 1.44$ & $8.2^{\mathrm{a}} \pm 1.68$ & $7.7^{\mathrm{b}} \pm 1.67$ \\
\hline T6 & $9.5^{\mathrm{a}} \pm 1.79$ & $9^{\mathrm{a}} \pm 1.68$ & $9.4^{\mathrm{a}} \pm 1.44$ & $9.25^{\mathrm{a}} \pm 1.68$ & $9.2^{\mathrm{a}} \pm 1.67$ \\
\hline
\end{tabular}

Mean values \pm standard deviation, Mean values followed by the same letter vertically do not differ at $p=$ 0.05 of significance

T1: - Air dried Fig without any treatments (control).

T2: - Air dried Fig immerged in sucrose solution only.

T3: - Air dried Fig immerged in (CMC) solution + calcium chloride solution + sucrose solution.

T4: - Air dried Plum without any treatment (control).

T5: -Air dried Plum immerged in sucrose solution only.

T6: - Air dried Plum immerged in (CMC) solution + calcium chloride solution + sucrose solution.

It was clear that using an osmotic agent (sucrose) for a given species, and coating agent (carboxy methyl cellulose) resulted in final products of significantly different quality. These differences could be due to the nature of the raw material, its chemical composition and using of coating agent.

For each sensory attribute, the effect of an osmotic agent (OA) and coating agent (CA) was determined in Table (4). The results confirmed the complexity of the interactions between sensory perception and the factors investigated. The majority of the sensory attributes investigated turned out to be significantly influenced by the osmotic and coating agent used for the fruit before drying.

\section{Effect of coating, drying methods on shear strength of dried Fig and Plum:-}

Shear strength of coating, non-coating and control samples were detected and have been presented in Fig. (1) From these data, it was clear that control samples ( $\mathrm{T} 1$ and $\mathrm{T} 4$ ) had the highest value, it were 27.85 and $39.47(\mathrm{~N})$, followed by coating samples (T3 and T6) which found to be 23.87 and $31.64(\mathrm{~N})$ meanwhile, noncoating samples (T2 and T5) had the lowest value and it were 20.12 and $25.96(\mathrm{~N})$ respectively, for both Fig and Plum, respectively. Similar results were reported for dried apple (Farzanch, et al., 2011) who noticed that edible coat causes the increase of shear strength due to decrease of solute up take to texture of samples. 
Fig. 1. Effect of coating, drying methods on shear strength (Neaten) of dried Fig and Plum:-

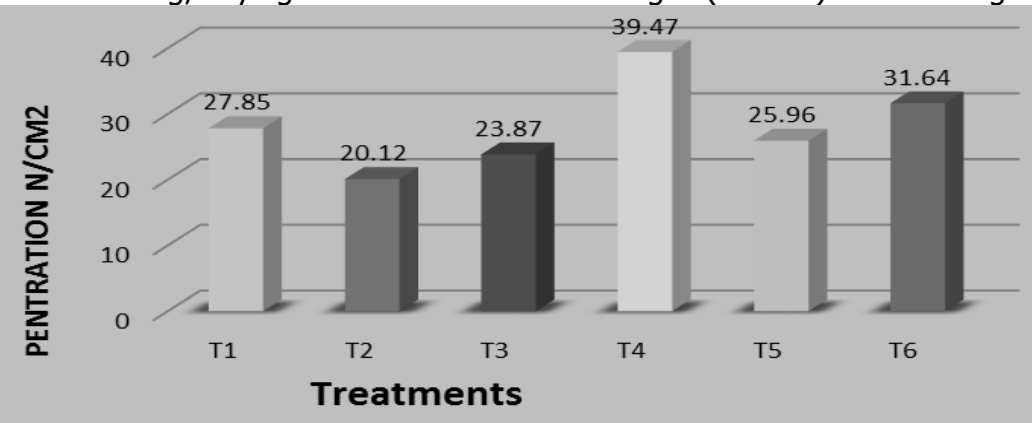

T1: - Air dried Fig without any treatments (control).

T2: - Air dried Fig immerged in sucrose solution only

T3: - Air dried Fig immerged in (CMC) solution + calcium chloride solution + sucrose solution.

T4: - Air dried Plum without any treatment (control).

T5: -Air dried Plum immerged in sucrose solution only.

T6: - Air dried Plum immerged in (CMC) solution + calcium chloride solution + sucrose solution.

The effect of using edible coating in weight loss, solid gain and water loss

\section{for osmotic dehydration Fig and Plum.}

The osmotic dehydration process was studied in terms of weight loss, water loss and solid gain Table. (5) and Fig. (2, 3). It was observed that the rate of weight loss, water loss and solid gain was higher in air dried samples after immerging in osmotic agent compared to these values which reported by air dried samples after immerging in edible coating and osmotic agent in both dehydrated Plum and Fig.

Table 5. Effect of using edible coating in weight loss, solid gain and water loss for osmotic dehydration Fig and Plum.

\begin{tabular}{|c|c|c|c|}
\hline \multirow{2}{*}{ Treatments } & Weight loss (WL \%) & Solid gain (SG \%) & Water loss (WLs \%) \\
\cline { 2 - 4 } & \multicolumn{3}{|c|}{ Fig } \\
\hline T2 & 29.03 & 13.31 & 44.10 \\
\hline T3 & 24.20 & 12.15 & 38.14 \\
\hline & \multicolumn{3}{|c|}{ Plum } \\
\hline T5 & 23.17 & 13.42 & 38.74 \\
\hline T6 & 20.98 & 10.01 & 33.34 \\
\hline
\end{tabular}

T2: - Air dried Fig immerged in sucrose solution only.

T3: - Air dried Fig immerged in (CMC) solution + calcium chloride solution + sucrose solution.

T5: -Air dried Plum immerged in sucrose solution only.

T6: - Air dried Plum immerged in (CMC) solution + calcium chloride solution + sucrose solution.

The initial high rates of water removal and solid uptake, followed by slower removal and uptake in the later stages were observed. Rapid loss of water and solid gain in the beginning is apparently due to the large osmotic driving force between the dilute sap of the fresh Plum and Fig and the surrounding hypertonic solution. Water loss and solid gain were most intensive in the first period of osmotic dehydration process. Weight reduction increased with an increase in concentration of sucrose syrup WL was very less in low sucrose concentration. This may be due to the fact that 
the lowest concentration of sucrose syrup may get diluted and reached the saturation point quickly, which would not help in removing water during the osmosis process. (Kiranoudis, et al., 1997).

Fig. 2. The effect of using edible coating on water loss and T.S.S. for osmotic dehydration Plum.

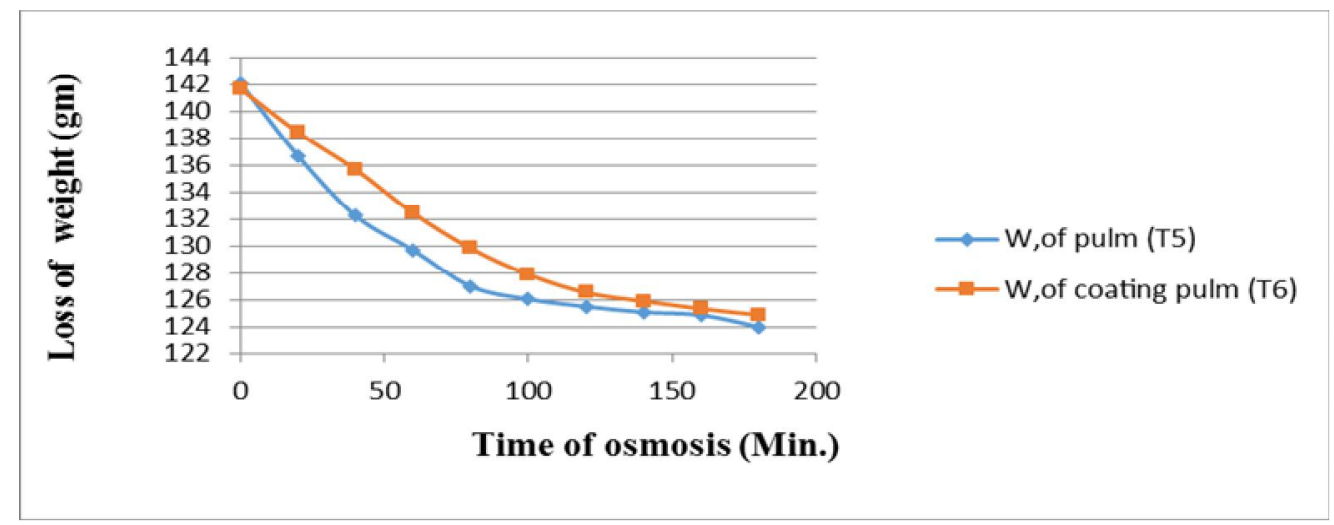

T2: - Air dried Fig immerged in sucrose solution only.

T3: - Air dried Fig immerged in (CMC) solution + calcium chloride solution + sucrose solution

T5: -Air dried Plum immerged in sucrose solution only.

T6: - Air dried Plum immerged in (CMC) solution + calcium chloride solution + sucrose solution.

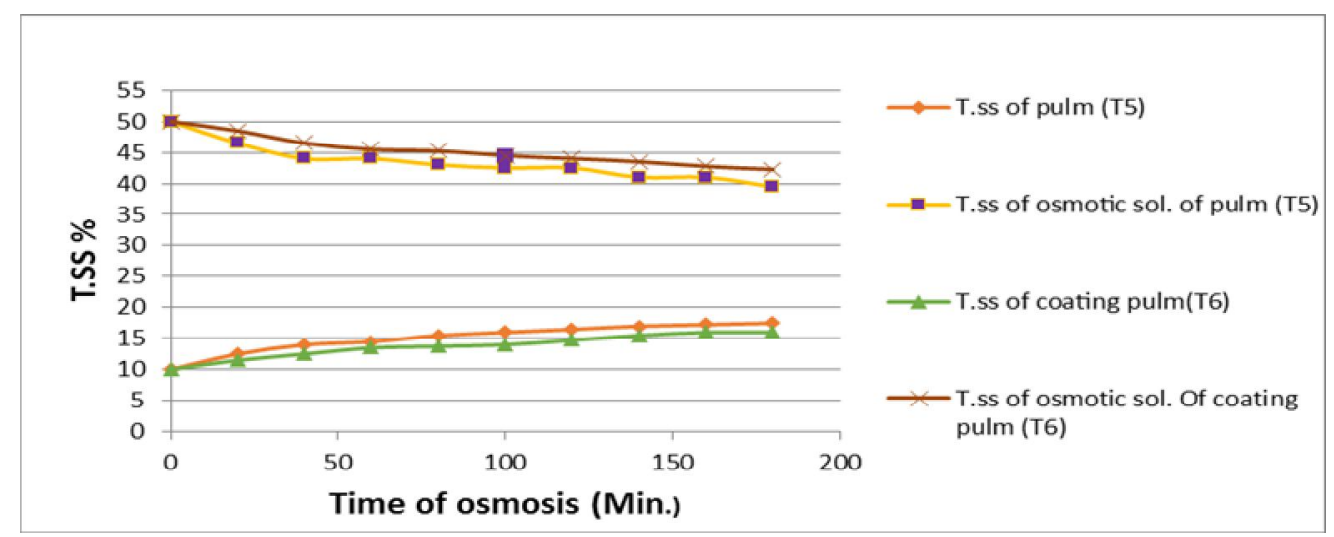

T2: - Air dried Fig immerged in sucrose solution only.

T3: - Air dried Fig immerged in (CMC) solution + calcium chloride solution + sucrose solution

T5: -Air dried Plum immerged in sucrose solution only.

T6: - Air dried Plum immerged in (CMC) solution + calcium chloride solution + sucrose solution.

On the other hands, the solid gains in all different samples are illustrated in Table. (5) and Fig. (2,3). The solid gain in air dried samples after immerging in osmotic agent increased rapidly during the first period of osmotic dehydration, and the amount of solid gain was significant at the end of osmotic dehydration. 
Fig. 3. The effect of using edible coating on water loss and T.S.S. for osmotic dehydration Fig.

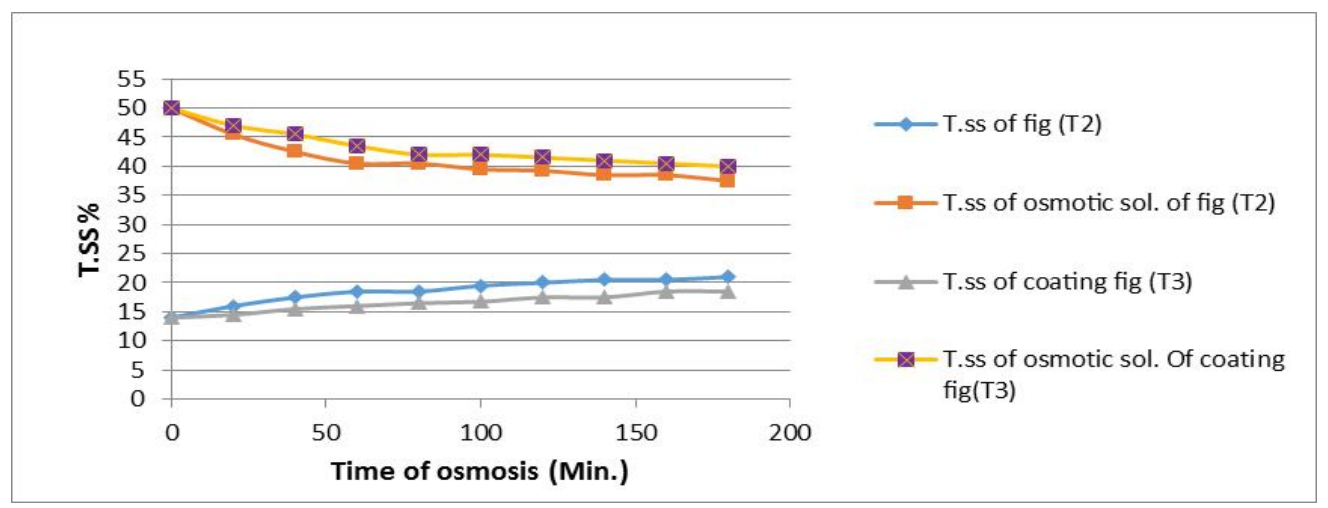

T2: - Air dried Fig immerged in sucrose solution only.

T3: - Air dried Fig immerged in (CMC) solution + calcium chloride solution + sucrose solution

T5: -Air dried Plum immerged in sucrose solution only.

T6: - Air dried Plum immerged in (CMC) solution + calcium chloride solution + sucrose solution.

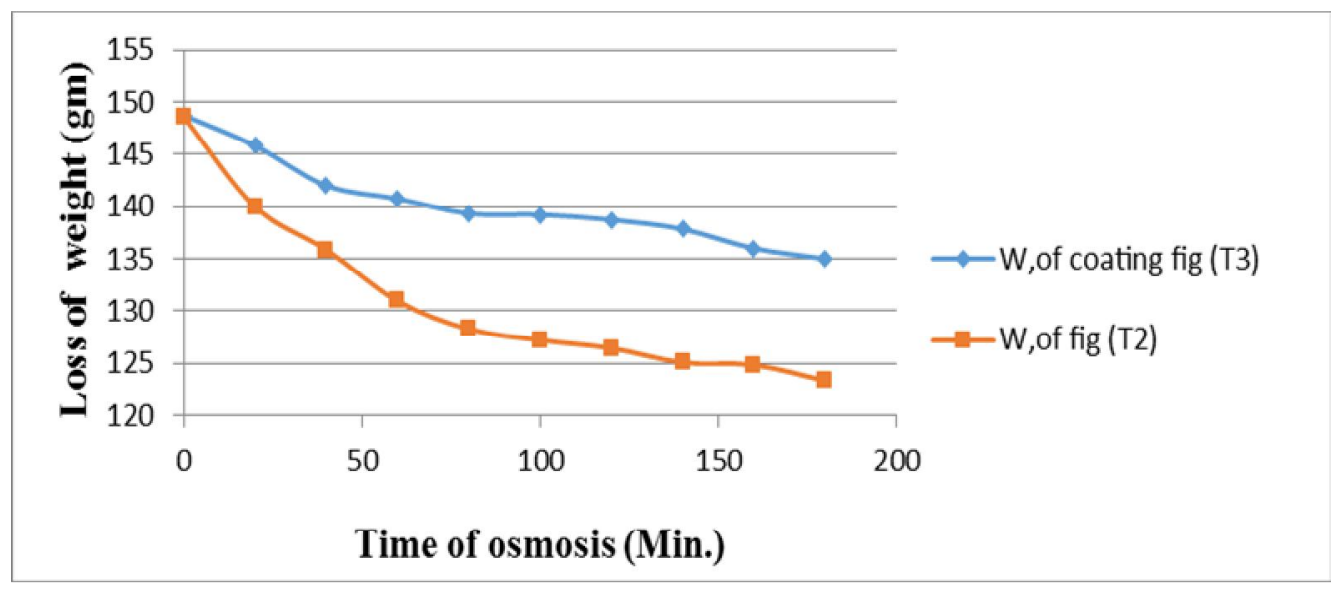

T2: - Air dried Fig immerged in sucrose solution only.

T3: - Air dried Fig immerged in (CMC) solution + calcium chloride solution + sucrose solution.

T5: -Air dried Plum immerged in sucrose solution only.

T6: - Air dried Plum immerged in (CMC) solution + calcium chloride solution + sucrose solution.

In contrast, the solid gains were negative (i. e. solid loss) for all coated samples as seen during the first $60 \mathrm{~min}$ of osmotic dehydration. These results verified the observation by Lenart and Dabrowska (1997) that a negative solid gain in maltodextrin-coated apples occurred after $10 \mathrm{~min}$ of osmotic dehydration in sucrose 
solution. However, the solid losses were rapid in the first period of osmotic dehydration and started to reduce thereafter.

One explanation for the negative solid gain in the air dried samples after immerging in edible coating and osmotic agent it could be due to dissolution of the coating material into the osmotic solution. However, the uptake was slow as compared to air dried samples after soaking in osmotic agent due to the presence of coating around the sample impeded the uptake of sucrose into the sample or it could be that the diffusion of the coating material into the osmotic medium opposed the movement of the sucrose molecules into the sample. This is consistent with the previous research results on sodium alginate coated and low methoxyl pectinatecoated potato and apple cubes (Khin et al., 2007).

\section{CONCLUSION}

Finally, through the aforementioned study, it could be clearly concluded that it is practically, economically and successfully to produce osmotic dehydrated Fig and Plum by using an edible coating agent (CMC) and sucrose syrup at T.S.S. (50\%).Besides, the high achieved overall palatability of those aforementioned products among different panelists and hence consumers.

\section{REFERENCES}

1. Association of Official Analytical Chemists (AOAC). 2012. Official methods of analysis Association of Official Analytical Chemists international, $19^{\text {th }}$ edition, Gaithersburg, Maryland, 20877- 2417.USA.

2. Bourne, M. C. 2002. Food Texture and Viscosity. Concept and Measurement, 2nd Ed. Academic Press, London. pp. 427.

3. Camirand, W.; Krochta, J. M.; Pavlath, A. E.; Wong, D. and Cole, M. E. 1992. Properties of some edible carbohydrate polymer coatings for potential use in osmotic dehydration. Carbohydrate Polymers. 17: 39-49.

4. Chang, C.; Yang, M.; Wen, H. and Chern, J. 2002. Estimation of total flavonoid content in Propolis by two complementary calorimetric methods. Journal of Food and Drug Analysis; 10:178-182.

5. Correa, J. L. G.; Pereira, L. M.; Vieiral, G. S. and Hubinger, M. D. 2010. Mass transfer kinetics of pulsed vacuum osmotic dehydration of guava. Journal of Food Engineering. 96:498- 504. 
6. Delia -Gabriela, D.; Camelia, M.; Diana- \$icoleta, R. and Mirela -Viorica, P. 2012. Comparative analysis of vitamin $\mathrm{C}$ content and antioxidant activity of some fruits extracts. Journal of Agroalimentary Processes and Technologies. 18 (3): 223-228.

7. El-Aouar, A. A.; Azoubel, M. P.; Barbosa, L. J. and Murr, X. E. F. 2006. Influence of osmotic agent on the osmotic dehydration of papaya (Carica papaya L.). Journal of Food Engineering. 75:267-274.

8. Emine, N. and Hisil, Y. 2013. Research on the phenolic compounds in Sarilop (Ficus carica) Fig variety. 38(5):267-274.

9. Farid, A. and Neda, A. 2014. Study of fruits nutritional aspects by measuring of related components. International Journal of Plant, Animal and Environmental Sciences. 4(2):746-751.

10. Farzanch, P.; Fatemian, H.; Hosseini, E.; Asadi, H. and Darvish, F. 2011. A comparative study on drying coating of osmotic treated apple rings. International Journal of Agricultural Science and Research. 2: 57-66.

11. Gupta, S.; Cox, S. and Abu- Ghannam, N. 2011. Effect of different drying temperatures on the moisture and phytochemical constituents of edible Irish brown seaweeds. LWT Food Science Technology. 1-7.

12. Hung, P. V. and Morita, N. 2009. Distribution of phenolic compounds in the graded flours milled from whole buckwheat grains and their antioxidant capacities. Food chemistry. 109: 325-331.

13. Ioannou, I.; Hafsa, I.; Hamdi, S.; Charbonnel, C. and Ghoul, M. 2012. Review of the effects of food processing and formulation on flavonoid and anthocyanin behavior. Journal of Food and Engineering. 111:208-217.

14. Khin, M. M.; Zhou, W. and Perera, C. O. 2007. Impact of process conditions and coatings on the dehydration efficiency and cellular structure of apple tissue during osmotic dehydration. Journal of Food Engineering. 79(3): 817-827.

15. J. O. Agbede

16. J. O. Agbede

17. Kiranoudis, C. T.; Tsami, E.; Maroulis, Z. B. and Marinos-Kouris, D. 1997. Drying kinetics of some fruits. Drying Technology. 15(5): 1399-1418.

18. Lee, J.; Durst, R. W. and Wrolstad, R. E. 2005. Determination of total monomeric anthocyanin pigment content of fruit juice, beverages, natural colorants, and wines by the $\mathrm{pH}$ differential method: collaborative study: J. of A.O.A.C International. 88:1269-1278.

19. Lenart, A. and Dabrowska, R. 1997. Osmotic dehydration of apples with polysaccharide coatings. Polish Journal of Food and Nutrition Science. 47(4):103112. 
20. Lindley, M. G.; Beyts, P. K.; Canales, I. and Borrego, F. 1993. Flavor modifying characteristics of the intense sweetener Meo hesperidin di hyrochalcone. J. Food Sci. 58:592-598.

21. Milala, J.; Kosmala, M.; Sójka, M.; Kołodziejczyk , K.; Zbrzeźniak, M. and Markowski, J. 2013. Plum pomaces as a potential source of dietary fiber: composition and antioxidant properties. Journal of Food Science and Technology. 50:1012-1017.

22. Mišljenović, N.; Koprivica, G.; Lević, L.J. and Kuljanin, T. 2009. Influence of monoand double- edible coating on improving of osmotic dehydration of apple in saccharose solution and sugar beet molasses. J. Process. Energy Agric. 13:184187.

23. Oliveira, A. P.; Silva, L. R.; depinho, P. G.; Gil-Izquierdo, A.; Valentao, P.; Silva, B. M.; Pereira, J. A. and Andrade, P. B.(2010b). Volatile profiling of Ficus carica varieties by HS-SPME and GC-IT-MS. Food Chem. 123: 548-557.

24. Panagiotou, N. M.; Karanthanos, V.T. and Maroulis, Z.B. 1999. Effect of osmotic agent on osmotic dehydration of fruits. Dry Technol. 17:175-189.

25. Singleton, V.L.; Orthofer, R. and Lamuela-Raventós, R.S. 1999. Analysis of total phenols and other oxidation substrates and antioxidants by means of FolinCiocalteau Reagent. Methods Enzymol. 299:152-178.

26. Zhao, Y. P. and Chang, K. C. 1995. Sulfite and starch affect color and carotenoids of dehydrated carrots (Daucus carota) during storage. Journal of Food Science. 60:324-347. 


\title{
التجفيف الأسموزى للتين و البرقوق
}

\author{
سهير السيا مصطفي - حسن إسماعيل عبد الحكيم - همت إبراهيم معتوق \\ قسم بحوث نكنولوجيا الحاصلات البستانية - معهر بحوث تكنولوجيا الأغذية - مركز البحوث \\ الزراعية - الجيزة مصر بكروبال
}

أجرى هذا البحث لدراسة تأثثر استخدام مو اد تغطيه صالحة للأكل ( كربوكسي ميثيل

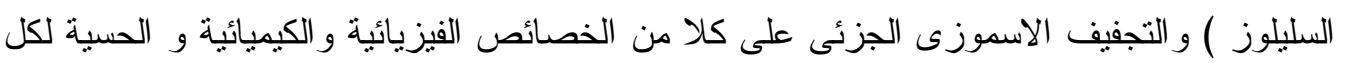

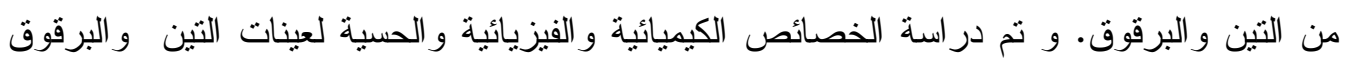

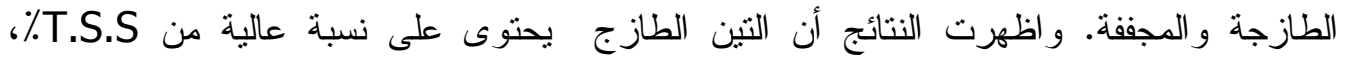

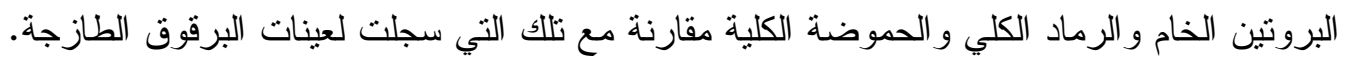
في الوقت نفسه، فقد سجلت عينات البرقوق الطازجة محتوى أعلى من التين الطازج في كل من نسبة لئل

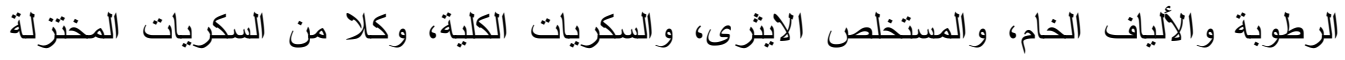
وغير المختزلة،و قيمة الرقم الهيدروجيني وحمض الأسكوربيك. وقد لوحظ أن هنالك اختلافات كبيرة

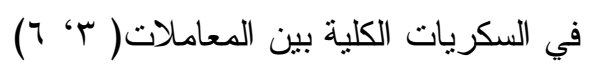
( لعينات التين و البرقوق المجف هو ائيا و و الذى نم غمره في محلول كربوكسى ميثيل سيللوز ثم

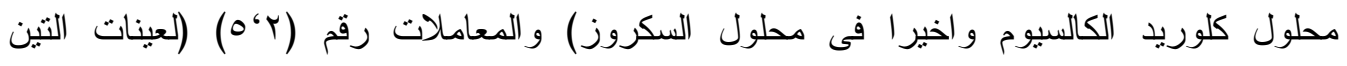
و البرقوق المفف هو ائيا والذى نم غمره في محلول السكروز) مقارنة مع عينات الكنترول (لعينات

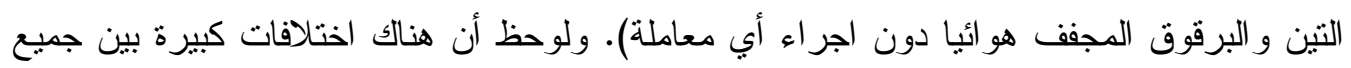

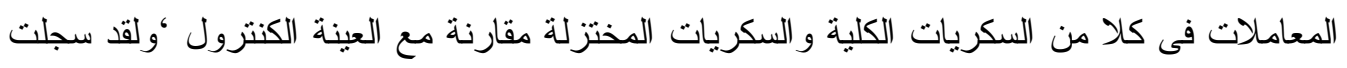

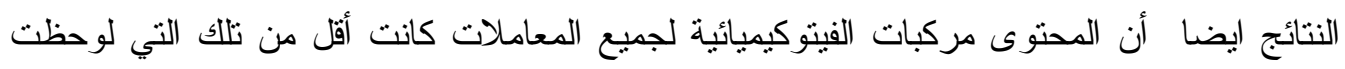

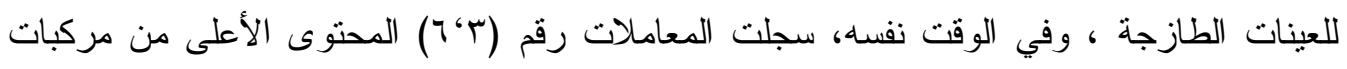

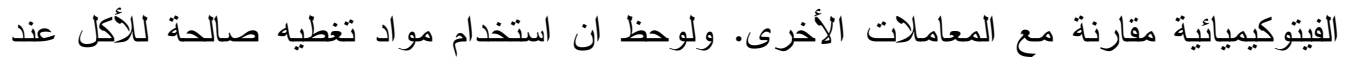
اجر اء التجفيف الاسموزى لكلا من التين و البرقوق ادى الى حماية مركبات الفئية الفيتوكيميائية. و أظهرت

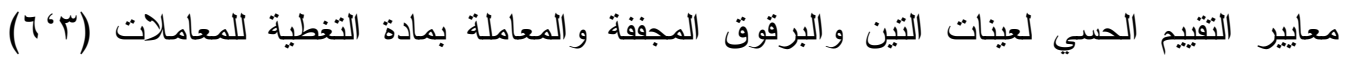

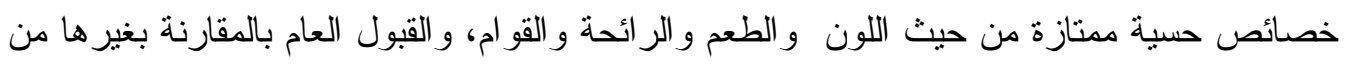

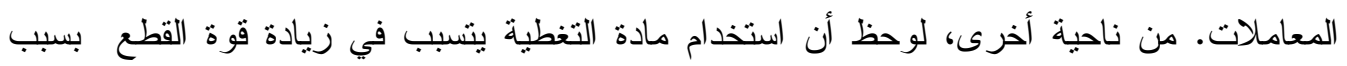

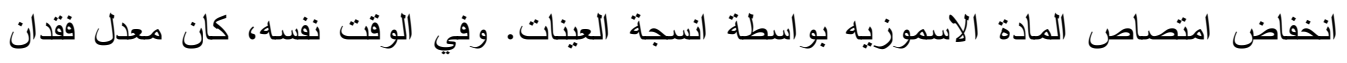

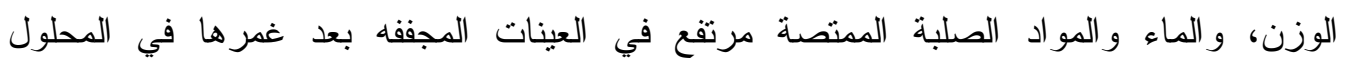
الاسموزي مقارنة مع تلك القيم التي سجلت للعينات المجففه بعد غمر ها في مادة التغطية و المحلول الاسموزي في كل من البرقوق و التين المجفف.

خلصت الدراسة إلى أن التين و البرقوق المجفق ولنف باستخدام مادة التغطية الماكولة

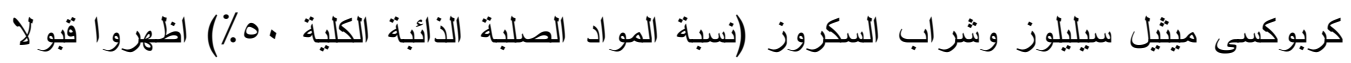

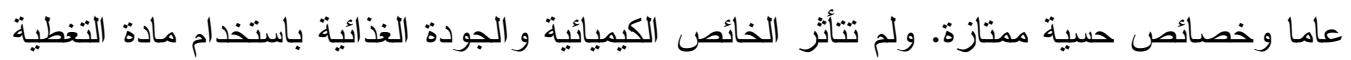

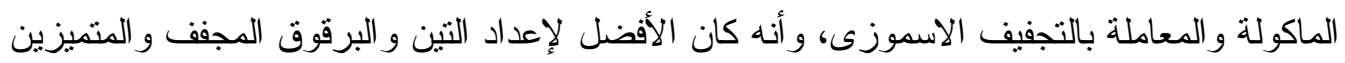

